\title{
JAMES LOUIS GIDDINGS, JR., 1909-1964
}

\author{
Helge LaRsen
}

\begin{abstract}
A MERICAN archaeology and Arctic archae$A$ ology have suffered a serious loss in the tragic and untimely death of Louis Giddings on December 9, 1964, from a thrombosis following an automobile accident. During the 25 years that Giddings was engaged in Arctic archaeology, he spent more seasons in the field and contributed more to our knowledge of Eskimo prehistory than anyone before him, and additional important publications and investigations were on the way when death overtook him.
\end{abstract}

With his inquisitive, analytical mind and an unusual alertness for scientific problems, Giddings was predestined to become a scientist. It was more or less accidental that he chose archaeology as his main field; it could just as well have been biology or some other natural science, in which he had a great interest and a wide knowledge, and he would no doubt have reached the top there as he did in our field. His versatility as a scientist manifests itself in his frequent use of auxiliary sciences in his effort to solve archaeological problems. Best known is his use of dendrochronology, in which he was an expert; and, in connection with the problems concerning the age of the Denbigh Flint complex and the formation of beach ridges, he resorted to geology, climatology, oceanography, and zoology, not to speak of his use of ethnology and folklore.

Giddings was a hard worker in the field as well as in the laboratory and at his desk. He never let danger prevent him from obtaining results. Disregarding warnings, he sometimes walked alone for weeks equipped only with what was absolutely necessary for survival in mountains or on the tundra; sometimes he rafted or traveled alone by canoe down the mighty Alaskan rivers, when one small accident could have been fatal. It is an irony of fate that he who time and again endangered his life in the wilds of the Arctic should be the victim of a traffic accident. He was untiring in his efforts to solve the problems encountered on his way, and an impressive list of publications shows not only his working capacity but also his remarkable versatility. His descriptive power is evident not only in his writings but also in his lectures, which he often spiced with his dry humor.
Louis Giddings was born in Caldwell, Texas, and attended Rice University at Houston. After studying English and biology for three years, he attended summer school at the University of Colorado. Fascinated by the Rocky Mountains, he took a job and remained in Colorado for a year. With his last $\$ 100$ he bought a ticket to Alaska, which was to be his home for the next 20 years. In Alaska he soon found his way to the University of Alaska, where he took a Bachelor of Science degree in 1931. In order to pay his way through school, Giddings had to work; and it is characteristic of him that he always managed to make each job interesting by finding some scientific problem connected with it. One of his jobs ultimately led him to his career. As a thawing engineer for a mining company he began to ponder over the possibility of dating the spruce trees caught in the frozen silt that covered the gold-bearing gravels. To this end he developed in the middle 1930's a local application of the Douglass tree-ring dating system and proved that it was applicable to the trees of the northern timberline. In 1938 his first two articles were printed in Tree-Ring Bulletin, and in the same year the University of Alaska made him an instructor.

From tree-ring dating it was only a short step into archaeology. Froelich G. Rainey, his friend and colleague at the University of Alaska, became interested in the possibility of dating Eskimo sites by tree-rings and invited Giddings to take part in the archaeological investigations at Point Hope which Rainey and I had planned for 1939. Giddings was fascinated by this new field, and during the first summer he made two major contributions to Eskimo archaeology. It was he who called my attention to the shallow depressions in the ground which appear to be Ipiutak house ruins and, at the end of the season when he was left alone on St. Lawrence Island to find datable wood from the Okvik and Old Bering Sea cultures, he managed to find and excavate the first Okvik house and to discover a new phase of Okvik culture.

In the following 25 years, Giddings was in the field almost every summer, setting a record for archaeological field work that will be hard to beat. His work was for the most part confined to an area within $200 \mathrm{mi}$. of Kotzebue that 
encompasses the upper reaches of the Kobuk River in the east, Cape Denbigh in the south, and Cape Prince of Wales in the west. It was natural for him to choose Kobuk River as his starting point because, during the winter of 1934-35 at Kotzebue, he had taken an interest in the Kobuk people and their culture; and furthermore, since Kobuk was near the northern timberline, he could apply his tree-ring dating method to archaeological investigations. Except for World War II, when he served in the U.S. Navy, and a canoe trip with his wife down the Mackenzie River in 1946, Giddings worked in the Kobuk area from 1940 to 1947. The results of his investigations were published in a monograph entitled The Arctic Woodland Culture of the Kobuk River, a model presentation of five major sites, all dated by the tree-ring method and each representing a phase of a special forest-edge culture.

In 1948, Giddings went to Norton Sound to try out the nearly 1000-year tree-ring chronology that he had established in the Kobuk area, but fate had decreed otherwise. At Iyatayet near Cape Denbigh he found and excavated a stratified site, the bottom layer of which contained remains of the now well-known Denbigh Flint complex, which in importance equals or even surpasses the discovery of the Thule and Dorset cultures. With this discovery Giddings had pushed Eskimo archaeology back 2000 years or more, and the Denbigh Flint complex or derivatives of it soon proved to form a stratum underlying all later forms of Eskimo culture from Bering Strait eastward to the Atlantic Ocean. Until 1952, Giddings devoted most of his time and efforts to further excavations at Cape Denbigh and to dating and interpreting his finds. The Archeology of Cape Denbigh appeared only a few months before his death; it is an impressive monograph of 330 pages, 80 plates, and numerous other illustrations that is a milestone in Eskimo archaeology and a worthy monument to its author.

Giddings realized that he could not extend his tree-ring chronology back far enough to date the Denbigh Flint complex and other early cultures he might encounter in his future work, and he then turned to another method of relative dating, namely, by means of the series of ocean beaches that occur in many places in Alaska. His beach-ridge dating is based on the Eskimo practice of camping or building houses on the front beach. As new beaches were formed, the remains of early occupations were left behind. From 1956 to 1961 Giddings investigated the coast between Cape Prince of Wales and Cape Krusenstern and returned with data that clearly substantiated his hypothesis. Cape Krusenstern, where he spent three seasons, proved to be the ideal place for this kind of dating. Remains of former habitation were found on almost all of the more than 100 beaches, and it was apparent that people had frequented this locality almost continuously from about 5000 years ago to the present. It is to be deeply regretted that death prevented Giddings from presenting his own complete account of these important investigations.

It is a strange fact that Giddings' field work came to an end in exactly the same area in which it began. His interpretation in the Kobuk report of three microcores and a microblade, which he had found in 1941 on one of the Kobuk sites (Onion Portage), as late survivals of an early trait bothered him so much that in 1961 he decided to return to the site and test it again. He soon discovered that his interpretation was correct; the ancient types did belong to an earlier occupation and not to the house in which they were found. The investigation further disclosed the existence of a huge stratified site which so far has yielded 30 culture-bearing layers and which may prove to be the most important site discovered by Giddings. He returned to this site in 1963 and prepared for an excavation of long duration. In 1964 he had a house built on the site for himself and his family. His plans for the 1965 season will now be carried out by his wife and his trusted student and collaborator, Douglas Anderson, supervised by his old friend, Froelich Rainey. It is the hope of Giddings' many friends and colleagues that this team, which we know will work in his spirit, may get the necessary means to continue his work and bring it to a conclusion. He deserves it.

\section{Publications of J. L. Giddings}

1938 Buried Wood from Fairbanks, Alaska. Tree-Ring Bulletin, Vol. 4, No. 4, pp. 3-5. Tucson.

Recent Tree-ring Work in Alaska. Tree-Ring Bulletin, Vol. 5, No. 2, p. 16. Tucson.

1940 The Application of Tree-ring Dates to Arctic Sites. Tree-Ring Bulletin, Vol. 7, No. 2, pp. 10-14. Tucson.

1941 Rock Paintings in Central Alaska. American Antiquity, Vol. 7, No. 1, pp. 69-70. Menasha.

Ethnographic Notes, Kobuk River Region, Alaska. The Kiva, Vol. 6, No. 7, pp. 25-8. Tucson. 
Dendrochronology in Northern Alaska. University of Arizona Bulletin, Vol. 12, No. 4, and University of Alaska Publication, Vol. 4. Tucson.

1942 Dated Sites on the Kobuk River. Tree-Ring Bulle. tin, Vol. 9, No. 1. Tucson.

1943 Some Climatic Aspects of Tree Growth in Alaska. Tree-Ring Bulletin, Vol. 9, No. 4, pp. 26-32. Tucson. A Plan for Mapping Arctic Sea Currents. The Geographical Review, Vol. 33, No. 2, p. 326. New York.

1944 Dated Eskimo Ruins of an Inland Zone. American Antiquity, Vol. 10, No. 2, pp. 113-34. Menasha.

1947 Mackenzie River Delta Chronology. Tree-Ring Bulletin, Vol. 13, No. 4, pp. 26-9. Tucson.

1948 Chronology of the Kobuk-Kotzebue Sites. TreeRing Bulletin, Vol. 14, No. 4, pp. 26-32. Tucson.

Diagonal Flaking from Kotzebue, Alaska. American Antiquity, Vol. 14, No. 2, p. 127. Menasha.

(with Ivar Skarland) Flint Stations in Central Alaska. American Antiquity, Vol. 14, No. 2, pp. 116-20. Menasha.

1949 Early Flint Horizons on the North Bering Sea Coast. Journal of the Washington Academy of Sciences, Vol. 39, No. 3, pp. 85-90. Washington.

1950 Early Man on the Bering Sea Coast. Annals of the New York Academy of Sciences, Ser. II, Vol. 13, No. 1, pp. 18-21. Baltimore.

Traces of Early Man on the North Bering Sea Coast. Bulletin, The University Museum, Vol. 14, No. 4, pp. 3-13. Philadelphia.

New Light on Early Man in Alaska. Bulletin of the Philadelphia Anthropological Society, Vol. 3, No. 2, pp. 2-4. Philadelphia.

Problems of Early Man in Alaska. Proceedings of the Alaska Science Conference, Washington, November 9-11, 1950. Bulletin, National Research Council, No. 122, p. 50 . Washington.

1951 The Denbigh Flint Complex. American Antiquity, Vol. 16, No. 3, pp. 193-203. Salt Lake City.

The Forest Edge at Norton Bay, Alaska. Tree-Ring Bulletin, Vol. 18, No. 1, pp. 2-6. Tucson.

Review: Ipiutak and the Arctic Whale Hunting Culture, by H. Larsen and F. G. Rainey. American Antiquity, Vol. 17, No. 2, pp. 158-60. Salt Lake City.

The Museum of the University of Alaska at Fairbanks. Museum, Vol. 4, No. 2, pp. 115-17. Paris.

1952 Ancient Bering Strait and Population Spread. Science in Alaska, pp. 85-102. Washington.

Driftwood and Problems of Arctic Sea Currents. Proceedings of the American Philosophical Society, Vol. 96, No. 2, pp. 129-42. Philadelphia.

The Arctic Woodland Culture of the Kobuk River. Museum Monographs, The University Museum. Philadelphia.

Observations on the "Eskimo Type" of Kinship and Social Structure. Anthropological Papers of the University of Alaska, Vol. 1, No. 1, pp. 5-10. College.
1953 Yukon River Spruce Growth. Tree-Ring Bulletin, Vol. 20, No. 1, pp. 2-5. Tucson.

(with D. M. Hopkins) Geological Background of the Iyatayet Archaeological Site, Cape Denbigh, Alaska. Smithsonian Miscellaneous Collections, Vol. 121, No. 11. Washington.

Review: A Summary of Tree-ring Dates from Some Southwestern Archaeological Sites, by T. L. Smiley. American Antiquity, Vol. 18, No. 3, p. 282. Salt Lake City.

A Holiday with the Padlimiut. Bulletin of the Phila delphia Anthropological Society, Vol. 7, No. 1, pp. 3-5. Philadelphia.

1954 Early Man in the Arctic. Scientific American, Vol. 150, No. 6, pp. 82-8. New York.

Tree-ring Dating in the American Arctic. Tree-Ring Bulletin, Vol. 20, Nos. 3-4, pp. 23-5. Tucson.

1955 The Denbigh Flint Complex Is Not Yet Dated. American Antiquity, Vol. 20, No. 4, pp. 375-6. Salt Lake City.

1956 Forest Eskimos: An Ethnographic Sketch of the Kobuk River People in the 1880's. Bulletin, The University Museum, Vol. 20, No. 2. Philadelphia.

The Burin Spall Artifact. Arctic, Vol. 9, No. 4, pp. 229-37. Montreal.

"Pillows" and Other Rare Flints. Anthropological Papers of the University of Alaska, Vol. 4, No, 2, pp. 117-20. College.

A Flint Site in Northernmost Manitoba. American Antiquity, Vol. 21, No. 3, pp. 255-68. Salt Lake City.

1957 Round Houses in the Western Arctic. American Antiquity, Vol. 23, No. 2, pp. 121-35. Salt Lake City. The Tenuous Beaufort Sea Archeology. Science in Alaska, 1954. Fairbanks.

Review: Archaeology of the Uyak Site, Kodiak Island, by Robert F. Heizer. American Anthropologist, Vol. 59, No. 2, pp. 371-2. Menasha.

1959 Archaeological Studies of Kotzebue Sound, Alaska. Year Book of the American Philosophical Society, 1959, pp. 513-14. Philadelphia.

1960 First Traces of Man in the Arctic. Natural History, Vol. 69 , No. 9, pp. 10-19. New York.

A View of Archeology about Bering Strait. Acta Arctica, Fasc. 12, pp. 27-33. Copenhagen.

The Archeology of Bering Strait. Current Anthropology, Vol. 1, No. 2, pp. 121-38. Chicago.

1961 Review: Archaeological Investigations of Inland and Coastal Sites of the Katmai National Monument, Alaska, by W. A. Davis. Archives of Archae$o \log y$, No. 4. Madison.

Kobuk River People. Studies of Northern Peoples, No. 1. College.

Alaskan Aboriginal Culture History. National Survey of Historic Sites and Buildings. U.S. National Park Service, Washington.

Cultural Continuities of Eskimos. American Antiquity, Vol. 27, No. 2, pp. 155-73. Salt Lake City. 
1962 (with Hans Georg Bandi) Eskimo-archäologische Strandwallenuntersuchungen auf Kap Krusenstern Nordwest-Alaska. Germania, 40, 1 halbband, pp. 1-21. Frankfort am Main.

Seven Discoveries of Bering Strait. Proceedings of the American Philosophical Society, Vol. 106, No. 2, pp. 89-93. Philadelphia.

Eskimos and Old Shorelines. The American Scholar, Vol. 31, No. 4, pp. 585-94. Washington.
Onion Portage and Other Flint Sites of the Kobuk River. Arctic Anthropology, Vol. 1, No. 1, pp. 6-27. Madison.

1964 The Archeology of Cape Denbigh. Brown University Bicentennial Publications, Providence.

\section{Nationalmuseet}

Copenhagen, Denmark May, 1965 